\title{
More BITE Than BARK: The Legal AND SOCIAL CONSEQUENCES OF MICROCHIPPING INDIVIDUALS WITH AlZHeIMER's DiSEASE
}

\author{
Elizabeth G. Currid*
}

II. A DESCRIPTION: MEET THE HUMAN-IMPLANTABLE MiCROCHIP.. 359

A. The Technology: What Makes It Tick......................................... 359

B. The Procedure: Method Behind the Madness ...........................360

C. The History: From 9/11 to Alzheimer's Disease........................360

D. Benefits: Sign Me Up .......................................................... 361

E. Technological and Procedural Problems: Loose Screws and Crossed Wires

II. LEGAL HISTORY: FROM WHENCE WE COME.....................................364

A. RFID Legislation: Where Is It? ................................................364

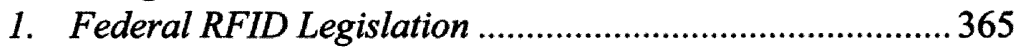

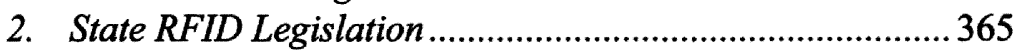

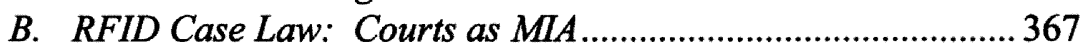

III. OTHER INFLUENTIAL AREAS OF LAW: A HINT OF WHAT'S TO

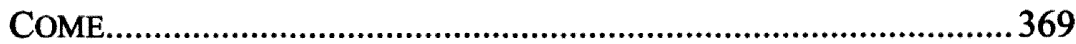

A. Electronic Surveillance and Wiretapping: Can You Hear Me

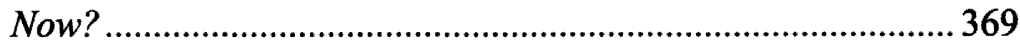

B. GPS: Locating Answers ........................................................... 371

IV. POTENTIAL PRIVACY PROBLEMS: OPENING THE DOOR FOR

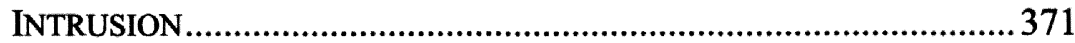

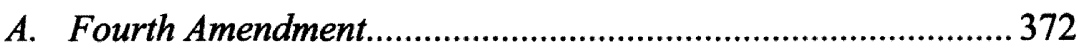

1. Subjective Expectation......................................................... 373

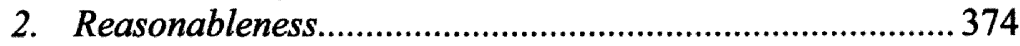

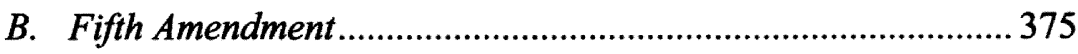

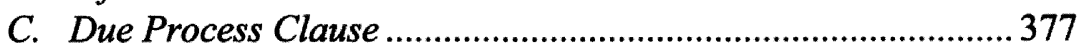

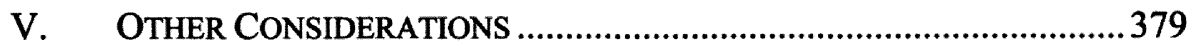

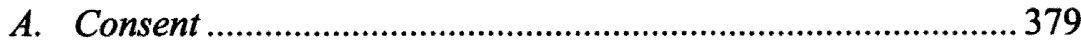

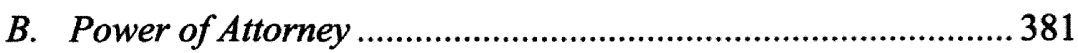

VI. SOLUTION: FORCING THE STATES INTO THE LIMELIGHT ..................382

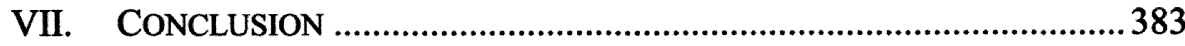

* J.D. Candidate, 2009, Indiana University School of Law - Indianapolis; B.A., 2006, Butler University. 


\section{INTRODUCTION: BIG BROTHER, WHERE ART THOU?}

Since the dawn of the computer age, authors and commentators have warned society about the potential pitfalls associated with the emergence of new technology. ${ }^{1}$ Zbigniew Brzezinski, National Security Advisor to President Carter, even deemed the new technological age "the major source of contemporary change." A number of societal problems, however, may accompany these wide-scale technological advances. ${ }^{3}$

The technetronic era involves the gradual appearance of a more controlled society. Such a society would be dominated by an elite, unrestrained by traditional values. Soon it will be possible to assert almost continuous surveillance over every citizen and maintain up-to-date complete files containing even the most personal information about the citizen. These files will be subject to instantaneous retrieval by the authorities. ${ }^{4}$

The human-implantable microchip, the newest member of the data-storing family and cousin to the Global Positioning System ("GPS"), may fulfill these Orwellian predictions and give Big Brother the perfect means by which to start watching.

This Note addresses the legal and social concerns resulting from implantation in Alzheimer's patients, arguing in favor of strict legislation as a precautionary measure. In Part II, this Note provides background information on the human-implantable microchip, briefly describing the technology, the procedure used in implantation, the resulting benefits, the technological and procedural problems, and the means by which it has gained publicity. Part III examines the law's limited response to the human-implantable microchip, especially in light of implantation in Alzheimer's patients. Part IV compares microchipping to other closely-related fields. In Part V, this Note identifies the legal and social problems that may result from microchipping. Finally, Part VI sets out a remedial proposal which urges each individual state to highly regulate microchipping for the sake of the elderly population.

1. See generally Nathan Brooks, Information Privacy, 54 FEDERAL LAWYER 4 (2007).

2. ZBIGNIEW BRZEZINSKI, BETWEEN TWO AGES: AMERICA'S ROLE IN THE TECHNETRONIC ERA 9 (1970).

3. See generally Conspiracy Research, http://www.conspiracyresearch.org/forums/ index.php?act=Print\&client=-printer\&f=50\&t=43349 (last visited January 2, 2009).

4. Id. 


\section{A DESCRIPTION: MEET THE HUMAN-IMPLANTABLE MICROCHIP}

\section{A. The Technology: What Makes It Tick}

Human-implantable microchips employ Radio Frequency Identification ("RFID") technologies, which "utilize radio waves to automatically identify individual items." $"$ On the most basic level, an RFID tag and an electromagnetic reader form the two main parts of an RFID system. ${ }^{6}$ RFID tags differ depending on the type of RFID technology used; human-implantable microchips are inserted under the skin and the reader is either handheld or mounted on the wall, usually in a hospital. ${ }^{7}$ For these passive tags, ${ }^{8}$ the detection and scanning range varies between one and ten feet. ${ }^{9}$ Although not utilized in current human-implantable microchips, an active tag boasts a read range of over 100 feet. ${ }^{10}$ More specifically, the RFID tag, or a capsule about the size of a rice grain, connotes the stereotypical human-implantable microchip. ${ }^{11}$ It is important to note that the microchip, as currently marketed, only stores an electronic ID and does not possess tracking capabilities. ${ }^{12}$

The RFID tag utilizes the Electronic Product Code ("EPC") to hold the information within the confines of the tag. ${ }^{13}$ The EPC system in most microchips, not just specifically in human-implantable microchips, rivals that employed in Universal Product Codes ("UPC"s). ${ }^{14}$ However, "UPC barcodes can only store seven bits of information, [while] EPC RFID tags can store up to 256 bits. In fact, the EPC system has enough capacity 'to provide unique identifiers for all items produced worldwide." "15 The EPC system in humanimplantable microchips is read-only, whereas other EPC systems may allow for read-write or read-write and tracking. ${ }^{16}$ The reader, however, is the true power

5. VeriChip Corporation, RFID 101, http://www.verichipcorp.com/content/company/ rfid101 (last visited November 12, 2007) [hereinafter RFID 101].

6. Id.

7. VeriChip Corporation, RFID Tags, http://www.verichipcorp.com/content/ company/rfidtags\#implantable (last visited November 12, 2007) [hereinafter RFID Tags].

8. Passive tags "are not powered by a battery, but instead rely on power generated by the reader." RFID 101, supra note 5.

9. RFID 101, supra note 5.

10. Id.

11. See RFID Tags, supra note 7.

12. $I d$.

13. See Reepal S. Dalal, Chipping Away at the Constitution: The Increasing Use of RFID Chips Could Lead to an Erosion of Privacy Rights, 86 B.U. L. REV. 485, 487 (2006).

14. Id.

15. Id.

16. See generally Elaine M. Ramesh, Time Enough? Consequences of Human Microchip Implantation, 8 RISK 373, 378 (1997) (describing the forms of implantable microchips). A read-write microchip "would be capable of carrying a set of information which could be expanded as necessary." Id. A read-write and tracking microchip would have all the capabilities of a read-write microchip, as well as the ability to "emit a radio signal which could be tracked." Id. 
source. ${ }^{17}$ Human-implantable microchips utilize passive RFID technology; therefore, they only activate in response to signals produced by the reader.

\section{B. The Procedure: Method Behind the Madness}

Simply put, the microchip is inserted beneath the skin through a shot-like procedure. "After a local anesthetic is administered, a large-gauge, hypodermic needle injects the chip under the skin on the back of the arm, midway between the elbow and the shoulder." ${ }^{20}$ After insertion under the skin, the microchip may be scanned by a reader. ${ }^{21}$ The passive nature of the RFID tag requires the reader to emit energy to bring the dormant microchip to life. ${ }^{22}$ In response, the chip transmits the tag's verification number that may be used to obtain personal information - usually medical in nature- from a computer database. $^{23}$

\section{The History: From 9/11 to Alzheimer's Disease}

RFID technology originated during World War II when the British "relied on RFID signals transmitted by their own aircraft to confirm their identity."24 In the 1970s, cattle ranchers began to microchip their livestock to track grazing and reproductive habits. ${ }^{25}$ Eventually, other animals became susceptible to microchipping, and "[i]n the 1990s, millions of chips were implanted in livestock, fish, pets, even racehorses."26

RFID technology came into vogue when the first RFID tags based on microchips infiltrated the marketplace in the $1980 \mathrm{~s}^{27}$ For-profit companies found microchips to be useful, placing them in a variety of inanimate objects, particularly as a vessel to monitor "the flow of goods and increase efficiency.",28

The burgeoning microchip industry soon realized an even bigger potential market in the implantation of human beings. ${ }^{29}$ The VeriChip Corporation

17. See RFID 101, supra note 5.

18. Id.

19. CNN.com, Microchips in Humans, http://www.cnn.com/2007/TECH/science/08/ 01/chips.humans.ap/index.html (last visited November 12, 2007) [hereinafter CNN, Microchips in Humans].

20. Id.

21. RFID Tags, supra note 7.

22. $I d$.

23. Id.

24. Gal Eschet, FIPs and PETs for RFID: Protecting Privacy in the Web of Radio Frequency Identification, 45 JURIMETRICS J. 301, 307 (2005).

25. CNN, Microchips in Humans, supra note 19.

26. Id.

27. Eschet, supra note 24.

28. See Kristi Heim, Microchips in People, Packaging and Pets Raise Privacy Questions, SEATTLE TIMES, Oct. 18, 2004, available at http://seattletimes.nwsource.com/html/business technology/2002066022_chipprivacy18.html [hereinafter Heim, Microchips in People].

29. See generally $\bar{i} d$. (presenting a timeline of microchipping, including the market's 
("VeriChip") established itself as the frontrunner in this arena, tracing its origination back to September 11, 2001, "when New York firemen were writing their badge ID numbers on their chests in case they were found injured or unconscious. ${ }^{, 30}$ Applied Digital capitalized on this need for more elaborate identification methods and created the VeriChip Corporation as a wholly-owned subsidiary in December 2001. ${ }^{31}$ Roughly three years after its creation, VeriChip received FDA approval for its human-implantable microchip in medical applications. ${ }^{32}$ The VeriChip Corporation is currently the only company in the world today offering an FDA-approved microchip. ${ }^{33}$

The company's revenues reflect its growing recognition. VeriChip reports a sale of 7,000 microchips worldwide, 2,000 of which have been implanted in humans. ${ }^{34}$ Currently, most of VeriChip's sales have occurred internationally. ${ }^{35}$ For instance, the Attorney General of Mexico and members of his staff use the microchip as a security pass to access secured areas. ${ }^{36}$ The company hopes to broaden its market, and is presently campaigning for implantation in supposed high-risk patients, particularly individuals with diabetes or Alzheimer's disease. $^{37}$

\section{Benefits: Sign Me Up}

Human-implantable microchips benefit society in a variety of ways. For instance, human-implantable microchips can restrict access to certain buildings or serve as an anti-kidnapping device for young children. ${ }^{38}$ In fact, officials established such child-protection services in Mexico. ${ }^{39}$ Also, it may aid employers in determining if job applicants have a criminal background or are legally present within the country. ${ }^{40}$ Most importantly for VeriChip's newest campaign, human-implantable microchips may be used to scan unconscious patients to gain access to their medical history. ${ }^{41}$

move toward human-implantable microchips).

30. See VeriChip Corporation, Company Profile, http://www.verichipcorp.com/ company.html (last visited November 12, 2007).

31. Id.

32. Id.

33. Id.

34. CNN, Microchips in Humans, supra note 19.

35. See Laurie Barclay, M.D., Medscape Today, FDA Approves Implantable Chip Used to Access Medical Records, http://www.medscape.com/viewarticle/491994 (last visited November $12,2007)$ [hereinafter Medscape Today].

36. See id.

37. See CNN, Microchips in Humans, supra note 19.

38. See Eschet, supra note 24, at 309.

39. See id.

40. See id.

41. See id. 


\section{E. Technological and Procedural Problems: Loose Screws and Crossed Wires}

Although human-implantable microchips benefit society in a number of ways, microchip technology and the procedure behind implantation and retrieval of information also bring about many difficulties. First, although the FDA found "reasonable assurance" in the safety of human-implantable microchips distributed by VeriChip, some commentators fear that health risks may exist nonetheless. ${ }^{42}$ In a letter from the FDA to Applied Digital Solutions that granted FDA approval, the administration listed various potential health risks, including "adverse tissue reaction, migration or failure of the implanted transponder, compromised information security, failure of the inserter or scanner, electromagnetic interference, electrical hazards, magnetic resonance imaging incompatibility, and needle stick." ${ }^{, 43}$ Chip migration occurs because "t]he capsules can migrate around the body or bury themselves deep in the arm. When that happens, a sensor X-ray and monitors are needed to locate the chip, and a plastic surgeon must cut away scar tissue that forms around the chip."4

Furthermore, "[a] series of veterinary and toxicology studies, dating to the mid-1990s, stated that chip implants had 'induced' malignant tumors in some lab mice and rats." 45 The study, however, presents several caveats. Not only may results differ between animals and humans, but also millions of animals underwent microchipping without developing cancer. ${ }^{46}$ Despite these caveats, leading cancer specialists still find the statistics worrisome.

Several leading critics have alleged administrative impropriety regarding FDA approval of the chips. ${ }^{48}$ The Associated Press reported:

The FDA is overseen by the Department of Health and Human Services, which, at the time of VeriChip's approval, was headed by Tommy Thompson. Two weeks after the device's approval took effect on Jan. 10, 2005, Thompson left his Cabinet post, and within five months was a board member of VeriChip Corp. . . . He was compensated in cash and stock options.

Second, the technology's relative permanence may substantially inconvenience

42. Todd Lewan, Chip Implants Linked to Animal Tumors, WASH. Post, Sept. 8, 2007, available at http://www.washingtonpost.com/wp-dyn/content/article/2007/09/08/AR200709 0800997 pf.html

43. Medscape Today, supra note 35 .

44. CNN, Microchips in Humans, supra note 19.

45. Lewan, supra note 42.

46. See id.

47. See id.

48. See id.

49. Id. 
a patient. "With an implantable chip, the person who's being tagged really doesn't have the ability to remove the tag or control the disclosure of its identity. ${ }^{50}$ Also, if an individual wants to remove the microchip, research shows that it cannot be easily or painlessly taken from the body. ${ }^{51}$

Third, opponents of human-implantable microchips seemingly disregard potential health risks and potential discomfort caused by the chip's permanence. ${ }^{52}$ Instead, they worry about unauthorized individuals gaining access to a chip's supposedly-guarded information. ${ }^{53}$ In essence, they argue that companies have not perfected the technology to prevent abuses. ${ }^{54}$ Thieves can actually engage in "spoofing," where they "make their own readers, aim them at unsuspecting individuals, and surreptitiously pluck people's IDs out of their arms."

In one example underlying these concerns, security researcher, Jonathan Westhues, "cracked" the VeriChip human-implantable microchip in less than two hours. "Westhues was able to read and clone the chip in the arm of a Wired News reporter in mere hours with a reader the size of an MP3 player and an antenna about five inches long." 57 Subsequent to his first crack of the VeriChip, Westhues demonstrated that even smaller technology-with a price tag of about twenty dollars-may access the VeriChip. ${ }^{58}$ Not only may the VeriChip's information be accessed, but the chip itself may also be cloned. ${ }^{59}$ "Once the VeriChip is read and cloned, the copy could be used for whatever purpose was intended for the initial chip, whether it be identifying a patient or accessing a secured location., 60

VeriChip's own chief executive officer admitted to the relative ease in stealing the sixteen digit ID number from others. ${ }^{61}$ Greater difficulty presents itself, however, in attempting to gain access to the database where the company stores the information that correlates to the number. ${ }^{62}$ For the technologicallysavvy, breaking into a password-protected database might not prove an insurmountable task. A student in the Netherlands demonstrated this potential threat by writing a virus small enough to fit on an RFID tag in only four

50. Heim, Microchips in People, supra note 28 (quoting Marc Rotenberg, director of the Electronic Privacy Information Center in Washington, D.C.) (internal quotations omitted).

51. See CNN, Microchips in Humans, supra note 19.

52. See, e.g., Medscape Today, supra note 35 (deemphasizing health risks while discussing non-biological concerns).

53. CNN, Microchips in Humans, supra note 19.

54. See id.

55. Id.

56. Nicole A. Ozer, Rights Chipped Away: RFID and Identification Documents, 2008 StAN. TECH. L. ReV. 1, 13 (2008).

57. $I d$.

58. Id.

59. Id.

60. Id.

61. CNN, Microchips in Humans, supra note 19.

62. See id. 
hours. ${ }^{63}$ Corruption of an RFID tag with a virus could allow a hacker access to any data stored on an institution's computer system by rendering the databases defenseless. ${ }^{64}$ In addition, RFID tags may share problems with biometric passports, "because the biometric information is broadcast 'in the clear' rather than in encrypted formats that avoid transmitting the information to unauthorized readers." $" 65$

A fourth kind of difficulty countering the benefits of the microchips is that hospitals and emergency medical centers must evolve technologically if microchipping gains popularity. According to VeriChip, by the beginning of August 2007, it had only trained and outfitted 100 hospitals around the country with the electromagnetic reader. ${ }^{66}$ The Government reported 4,927 community hospitals located in the United States in 2002 . $^{67}$ Thus, only about two percent of all hospitals currently possess the requisite technology to employ the humanimplantable microchips. The burden of bringing all relevant organizations up to speed would include the substantial price of this equipment. For instance, one high-powered reader for a passive tag costs between $\$ 1,000$ and $\$ 3,000$-a significant amount that does not account for the other expenses incurred in updating to RFID technology. 68

Finally, although the current FDA-approved version of the chip possesses no tracking capabilities, other versions of the human-implantable microchip may enable monitoring of a person's whereabouts. 69 "If each chip emitted a signal of a unique identifying frequency, implanted individuals could be tracked by simply dialing up the correct signal. The implantable microchip could be monitored from the police station, a car or perhaps even a helicopter. . . ."70 Such a possibility may seem remote, but in fact, biomedical researchers currently track animals with analogous devices. ${ }^{71}$

\section{LEGAL HISTORY: FROM WHENCE WE COME}

\section{A. RFID Legislation: Where Is It?}

RFID technology has been utilized for several decades. ${ }^{72}$ It has primarily

63. Kristina M. Willingham, Scanning Legislative Efforts: Current RFID Legislation Suffers from Misguided Fears, 11 N.C. BANKING INST. 313, 319 (March 2007).

64. See id.

65. Medscape Today, supra note 35.

66. CNN, Microchips in Humans, supra note 19.

67. Press Release, U.S. Census Bureau, Statistical Abstract of the United States: 20042005, http://www.census.gov/Press-Release/www/releases/archives/health_table158.pdf (last visited Feb. 20, 2009).

68. See RFID 101, supra note 5. note 19.

69. See Ramesh, supra note 16, at 374. See also CNN, Microchips in Humans, supra

70. Id. at 385 .

71. Id.

72. See RFID Journal, Is RFID New?, http://www.rfidjournal.com/faq/16/52 (last visited 
focused, however, on implantation of inanimate objects. ${ }^{73}$ Thus, legislatures have had time to fashion laws to protect these industries, as well as consumers, against abuses.

\section{Federal RFID Legislation}

Despite the existing RFID legislation, the federal Government has failed to deal directly with RFID technology. ${ }^{74}$ In 2004, the Opt Out of ID Chips Act ("OOICA") made its way to Congress. 75 OOICA would have required companies to place a warning label on all RFID-tagged products detailing the presence of an RFID tag and would give consumers the option to remove or disable it. $^{76}$ The bill, however, failed to garner support and died in a House committee. $^{77}$

In 2005, the federal Government acknowledged RFID technology in the Real ID Act. ${ }^{78}$ The legislation requires that state drivers' licenses conform to a set of federal standards. ${ }^{79}$ Although the federal guidelines do not require the inclusion of RFID tags in drivers' licenses, they do allow the Secretary of Homeland Security to impose such a condition if so desired. ${ }^{80}$ Some analysts argue that the Secretary will indeed pursue this course of action. ${ }^{81}$

\section{State RFID Legislation}

Unlike the federal Government, states have been far more willing to regulate RFID. ${ }^{82}$ Many legislators have attempted to pass state RFID legislation in hopes of influencing future federal action. ${ }^{83}$ Since 2004 , five states-New Hampshire, Utah, Virginia, Wisconsin, and Wyoming-have enacted RFID legislation. $^{84}$ Also, a number of other states have proposed RFID legislation. ${ }^{85}$ Furthermore, the states' governors have not hindered the legislature. ${ }^{86}$ Only governors in California and Rhode Island have vetoed RFID legislation. ${ }^{87}$

Nov. 3, 2007).

73. See id.

74. See Willingham, supra note 63 , at 326.

75. See Laura Hildner, Defusing the Threat of RFID: Protecting Consumer Privacy Through Technology-Specific Legislation at the State Level, 41 Harv. C.R.-C.L. L. REV. 133, 151 (2006).

76. See Id.

77. See Id.

78. See Willingham, supra note 63 , at 327.

79. See id.

80. See id.

81. Anita Ramasastry, CNN.com, Why the 'Real ID' Act Is a Real Mess, http://www.cnn.com/2005/LAW/08/12/ramasastry.ids/index.html (Feb. 20, 2009).

82. See Willingham, supra note 63 , at 327.

83. See id.

84. See id.

85. See id.

86. See id.

87. See id. 
For the most part, legislation tends to fall into three general categories: "restrictive, disclosure, or extreme privacy legislation." ${ }^{88}$ Living up to its name, restrictive legislation places restrictions or conditions on the use of RFID technology ${ }^{89}$ The Identity Information Protection Act of 2006 ("IIPA") serves as an example. ${ }^{90}$ Among a number of other provisions, IIPA requires "that there must be mutual authentication between the RFID tag and the RFID reader when personal information is being transmitted." 91

Similar to OOICA, which never made it out of committee, state disclosure legislation requires those employing RFID to tell their consumers of its use. ${ }^{92}$ This may be accomplished by placing signs near an RFID reader, informing a customer of the location of all readers via writing, or through a website. ${ }^{93}$ Other stipulations may also apply:

[d]isclosure legislation may also require that any product containing an RFID tag bear a symbol or label that notifies the customer that the product contains an RFID tag. A New Hampshire bill goes one step further by stipulating that any product containing an RFID tag must bear a "universally accepted symbol" that indicates the presence of an RFID tag. ${ }^{94}$

Finally, some states have adopted extreme privacy legislation, most discussing human-implantable microchips. ${ }^{95}$ Simply put, extreme privacy legislation "assumes the worst possible uses of RFID and then attempts to preemptively regulate them." 96 Wisconsin recently enacted a prohibition against any person forcing another individual to be microchipped. ${ }^{97}$ Both Ohio and Missouri legislatures have introduced acts that would forbid employers from requiring employees to be implanted with an RFID tag. ${ }^{98}$ Likewise, even though the Governor ultimately vetoed the proposed acts, the Rhode Island legislature passed a number of bills disallowing state agencies and municipalities from using RFID to track its citizens. ${ }^{99}$

Most recently, Oklahoma made the headlines with its proposed RFID legislation, with some legislators advocating for microchip implantation in human

88. Willingham, supra note 63 , at 328.

89. See id.

90. See id.

91. See id. at 328-29.

92. See id. at 326, 333.

93. See id.

94. Willingham, supra note 63 , at 326.

95. See id. at 331 .

96. Id. at 332 .

97. Id. at 331 .

98. See id. at 332 .

99. See id. at 327-28. 
beings, specifically in individuals convicted of violent crimes. 100 "The measure, approved by the Senate, authorizes microchip implants for persons convicted of one or more of 19 violent offenses who have to serve at least 85 percent of their sentence." 101 The legislation, however, was sent back to committee, but only after legislators raised a variety of concerns about violation of civil liberties. ${ }^{102}$ No matter what type of legislation a state enacts, the compulsion to regulate microchipping is unlikely to dissipate, especially since current legislation indicates an overall sentiment that RFID is " a risky technology requiring specific regulations to prevent identity theft' and protect privacy." 103

\section{B. RFID Case Law: Courts as MIA}

Although several state legislatures have delved into the world of RFID, few litigated cases make reference to the technology, including humanimplantable microchips. In fact, the sponsor of the privacy-conscious Wisconsin law admitted that no known cases of forcible implantation of an RFID tag exist. $^{104}$

Despite the scant case law dealing with microchipping, two cases in particular briefly discuss it. The first, State v. 1993 Chevrolet Pickup, demonstrates widespread fears accompanying RFID technology and microchipping, specifically of a surveillance empire of sorts. ${ }^{105}$ In 1993 Chevrolet Pickup, agents from the Eastern Montana Drug Task Force raided several unlocked trash cans belonging to the defendant, a suspect who was thought to be operating a methamphetamine laboratory. ${ }^{106}$ Items found in the garbage cans formed the basis for a search warrant of the defendant's belongings. ${ }^{107}$ Subsequent to the search, the agents arrested the defendant. ${ }^{108}$ In turn, the defendant argued against the legitimacy of the search warrant. ${ }^{109}$ The Montana Supreme Court held that the search warrant was valid, based on the agents' raid of the defendant's trash cans. ${ }^{110}$ The Court based its decision on the lack of privacy inherent in society. ${ }^{111}$

100. See KOSU, House Rejects Forced Microchip Implants for Violent Criminals, http://www.publicbroadcasting.net/kosu/news.newsmain?action=article\&ARTICLE_ID=108726 5\&sectionID=1 (last visited Nov. 12, 2007).

101. Id.

102. See id.

103. Willingham, supra note 63, at 335 (quoting Douglas B. Farry, RFID Product News, Does California's New Legislation Ignore Advantages of RFID?, http:// www.rfidproduct news.com/issues/2006.09/ legal.php (last visited Feb. 3, 2007)).

104. Id. at 331-32.

105. State v. 1993 Chevrolet Pickup, 116 P.3d 800, 806 (Mont. 2005).

106. Id. at 802 .

107. Id.

108. Id.

109. Id.

110. Id.

111. See 1993 Chevrolet Pickup, 116 P.3d at 806. 
Like it or not, I live in a society that accepts virtual strip searches at airports; surveillance cameras; "discount" cards that record my buying habits; bar codes; "cookies" and spywear [sic] on my computer; on-line access to satellite technology that can image my back yard; and microchip radio frequency identification devices already implanted in the family dog and soon to be integrated into my groceries, my credit cards, my cash and my new underwear. $^{112}$

This lack of privacy can similarly be imported into the microchipping context.

The dissent in Rise v. State of Oregon, however, provides a hint of the legal problems that may arise in the future, particularly in regards to microchipping. ${ }^{113}$ In Rise, prison inmates brought a claim against the state of Oregon, protesting the State's requirements that blood be extracted from certain inmates for DNA testing and the results be recorded in Oregon's DNA data bank. ${ }^{114}$ Although the case has since been overruled, the dissent presented the only existing case law mentioning human-implantable microchips and the constitutional implications from such a practice. ${ }^{15}$

Today, technology allows us to insert a microchip beneath the skin and later scan the microchip for a positive identification of the individual. Under the majority's analysis, such microchip insertion would be permissible because of its function to identify criminals, even though it violates our precedent regarding the intrusiveness of an invasion of bodily integrity. As technology develops, there may well be other, more intrusive possibilities for verifying an individual's identity. Surely, the Fourth Amendment's proscriptions against search procedures that invade bodily integrity shield the individual from such intrusions, even though the procedures could yield enormously useful fruits for regular law enforcement purposes. $^{116}$

The dissent is worrying about other possibilities beyond even the realm of microchipping and implies that perhaps the Fourth Amendment would serve as some sort of protection against the risks inherent in such possibilities.

112. Id. (Nelson, J., concurring).

113. See Rise v. Oregon, 59 F.3d 1556, 1569 (9th Cir. 1995).

114. Id. at 1558 .

115. See id.

116. Id. at 1569 n.3. 


\section{OTHER INFLUENTIAL AREAS OF LAW: A HINT OF WHAT'S TO COME}

\section{A. Electronic Surveillance and Wiretapping: Can You Hear Me Now?}

In contrast to the lack of legislation specifically detailing microchipping, " $[t]$ he Federal government and virtually all states have enacted statutory provisions dealing with electronic surveillance and wiretapping." 117 At the federal level, Congress enacted the Electronic Communications Privacy Act ("ECPA") of 1986. "Among the goals of the ECPA was a desire to update eavesdropping regulations to address current technology and avoid unnecessary restrictions on then emerging fields of communications technology."119 In an attempt to achieve these ends, Congress deemed several acts criminal, including unlawful access of stored information. ${ }^{120}$ Interestingly enough, the ECPA explicitly states that tracking by way of RFID technology is an exclusion to the wiretapping rules, a provision which was later upheld by the courts. ${ }^{121}$

In an effort to keep up with changing technology, Congress adopted the Communications Assistance for Law Enforcement Act ("CALEA") in 1994. ${ }^{122}$ This is the only legislation that even acknowledges location privacy, although it makes no specific mention of RFID. ${ }^{123}$ CALEA actually deals with telephone communications:

CALEA requires telecommunication carriers to make their equipment capable of transmitting "call-identifying information," but it also specifically prohibits the use of technology (other than pen registers and similar devices) that would reveal the user's physical location. The interpretation and enforcement of the statute is delegated to the Federal Communications Commission ("FCC"), making the agency responsible for promulgating procedures to ensure compliance. ${ }^{124}$

The FCC's oversight of location privacy "may be extended to cover RFID technology." 125 The FCC's recent policies in regards to location privacy, how-

117. Oleg Kobelev, Big Brother on a Tiny Chip: Ushering in the Age of Global Surveillance through the Use of Radio Frequency Identification Technology and the Need for Legislative Response, 6 N.C. J. L. \& TECH. 325, 336 (2005).

118. Id.

119. Id.

120. Id. at 337.

121. Id.

122. See generally Communications Assistance for Law Enforcement Act, Pub. L. No. 103-414, 108 Stat. 4279 (1994).

123. Kobelev, supra note 117 , at 338.

124. Id. (footnote omitted).

125. Id. 
ever, may require a Congressional push in the direction of privacy-friendly policies. 126

Following CALEA's enactment, the biggest expansion of governmental authority regarding surveillance and wiretapping occurred after the fateful events of September 11, 2001. ${ }^{127}$ Congress passed the Uniting and Strengthening America by Providing Appropriate Tools Required to Intercept and Obstruct Terrorism Act ("USA PATRIOT Act"), the Intelligence Authorization Act for Fiscal Year 2002, and the Department of Homeland Security Act of 2002. ${ }^{128}$

Although enacted in different years, federal RFID legislation relates to one another, tied together by a common thread.

In short, all of the existing legislative acts in which Congress addressed the issue of privacy seem to either specifically allow or at least tacitly permit virtually unrestricted tracking and monitoring of individuals by both the government and private actors. ... While in the pre-RFID world this situation was tolerable simply due to the limitations and expense of the available tracking technology, the advent of RFID, with its cheap and efficient tracking mechanisms and its ubiquity in the marketplace, greatly magnifies the threat to people's privacy.

The Supreme Court has also addressed electronic surveillance. In Katz v. United States, the Supreme Court held that the United States Government violated the petitioner's rights to privacy under the Fourth Amendment. ${ }^{130}$ In his concurrence, Justin Harlan based his decision on the application of a two-part privacy test to determine when law enforcement activity constitutes a search. ${ }^{131}$ The following two criteria must be proven in order for law enforcement activity to constitute a search: first, a person has exhibited an actual subjective expectation of privacy and second, the expectation is one that society is prepared to recognize as "reasonable." 132 Subsequently, the Supreme Court has adopted

126. See id.

127. See id. at 336.

128. See generally the Uniting and Strengthening America by Providing Appropriate Tools Required to Intercept and Obstruct Terrorism Act, Pub. L. No. 107-56, 115 Stat. 272 (2001); the Intelligence Authorization Act for Fiscal Year 2002, Pub. L. No. 107-108, 115 Stat. 1394 (2001); and the Department of Homeland Security Act of 2002, Pub. L. No. 107-296, 116 Stat. 2135 (2002).

129. Id. at 338-39.

130. See Katz v. United States, 389 U.S. 347 (1967).

131. Id. at 361 .

132. Id. 
this formulation in determining Government violations of the rights to privacy under the Fourth Amendment.

\section{B. GPS: Locating Answers}

The GPS, a specific type of electronic surveillance, is comparable to the human-implantable microchip in a number of ways. For instance, one of the main criticisms of the microchip-invasion of privacy rights-has also been a source of controversy in previous battles over GPS. ${ }^{134}$ GPS caused outrage among privacy advocates because it actually "allows law enforcement officials to monitor an individual's precise movements for weeks or months at a time." ${ }^{135}$ An upside exists, however, because GPS stays remote to the individual, located in cell phones or car navigation systems. ${ }^{136}$ The humanimplantable microchip, on the other hand, could turn into GPS on steroids-a round-the-clock monitoring system completely embedded within a person's body. ${ }^{137}$ The Supreme Court has warned about advancing GPS to the next level. ${ }^{138}$ It has stated that "the [Fourth Amendment] rule we adopt must take account of more sophisticated systems that are already in use or in development."139

Courts have also recognized the privacy implications associated with GPS. ${ }^{140}$ A total of seven courts, three federal and four state, have considered the permissibility of law enforcement's use of GPS-tracking devices, with no clear consensus emerging. ${ }^{141}$ "Of these seven cases, one declined to resolve the matter and the remaining six split evenly on the question of whether law enforcement should be required to obtain a warrant before engaging in the surreptitious use of a GPS tracking device."142 In essence, a clear train of thought has not yet emerged indicating how the Supreme Court would rule on such a question. 143

\section{Potential PRIVACY PROBLEMS: OPENING THE DOOR FOR INTRUSION}

These several areas of the law, all similar in their own ways to microchipping, have aroused a number of sentiments regarding their constitutionality,

133. Kobelev, supra note 117 , at 333-35.

134. See Renee McDonald Hutchins, Tied up in Knotts? GPS Technology and the Fourth Amendment, 55 UCLA L. REV. 409, 409 (2007).

135. Id.

136. See generally id. (detailing the science and uses behind GPS technology).

137. See id. at 421.

138. Kyllo v. United States, 533 U.S. 27, 36 (2001).

139. Id.

140. Hutchins, supra note 134, at 445 .

141. Id.

142. Id.

143. Id. 
especially in the area of privacy. Due to the comparable nature of electronic surveillance and GPS to microchipping, these same problems may potentially arise when human-implantable microchips really find their niche in the worldwide market. The right to privacy originates from language in the First, Fourth, Fifth, and Ninth Amendments, as well as throughout the common law. ${ }^{144}$ In Griswold v. Connecticut, the Supreme Court introduced the concept of the right to privacy as a constitutionally-protected interest, holding that privacy stems from the penumbras in the Bill of Rights. ${ }^{145}$

Human-implantable microchips threaten an Alzheimer's patient's rights to privacy. Although there has been little abuse of the chips, the technology is still in its developmental stages and may present problems in the future. ${ }^{146}$ Similar to the fears that accompany electronic surveillance, wiretapping, and GPS, microchips also produce a number of Orwellian visions, a society of microchipped human beings, constantly monitored by Big Brother. As previously mentioned, Congress enacted the ECPA in part to avoid eavesdropping. ${ }^{147}$ Later, with the enactment of CALEA in 1994 and the USA Patriot Act, Congress even further recognized these privacy concerns. ${ }^{148}$ In regard to GPS, case law has also addressed rights to privacy. ${ }_{150}^{149}$ Microchipping will be no exception to the attack on an individual's privacy. ${ }^{150}$ Now, instead of just worrying about eavesdropping and GPS monitoring, society must worry about the increased likelihood of identify theft or compulsory chipping by the Government. The following section addresses potential Government abuses of microchipping, even though they may seem improbable right now.

\section{A. Fourth Amendment}

Privacy rights arise from several passages in the Constitution. The Fourth Amendment, for example, protects an individual from unreasonable search and seizure by the Government. ${ }^{151}$ Cases involving electronic surveillance and wiretapping have shown that courts often first attempt to determine whether a person has exhibited an actual, subjective expectation of privacy and second, whether the expectation is one society recognizes as "reasonable."

144. See Ramesh, supra note 16.

145. Griswold v. Connecticut, 381 U.S. 479, 484 (1965).

146. See, e.g., Lynum v. Dept. of Justice, No. 3:07-CV-1652-B ECF, 2007 WL 3287333 (N.D. Tex. Nov. 5, 2007) (The plaintiff alleges that microchips were forced into her ears and cameras into her eyes. This case illustrates the type of ridiculous allegations that currently exist with regard to microchip abuse and how few, if any, serious right to privacy claims have actually been brought in regards to the technology.).

147. Kobelev, supra note 117 , at 336.

148. See id. at 336-38.

149. E.g., Kyllo, 533 U.S. at 27.

150. Ramesh, supra note 16 , at 374 .

151. See id. at 391.

152. Kyllo, 533 U.S. at 27-28. 


\section{Subjective Expectation}

The Supreme Court has examined subjective expectation in a variety of cases, some dealing with bodily invasion and others addressing external objects. ${ }^{153}$ For example, some courts have examined whether the taking of blood samples would be unconstitutional under the Fourth Amendment. ${ }^{154}$ The Second Circuit, agreeing with a Third Circuit opinion, ${ }^{155}$ found that personal information should not be readily accessible and subsequently created a subjective expectation of privacy. ${ }^{156}$

The court did limit the protection, however, stating that individuals cannot expect to have a constitutionally protected privacy interest in matters that already exist in the public record. ${ }^{157}$ The Supreme Court has reinforced this limitation, holding that anything already observable to the public does not qualify for Fourth Amendment protection. ${ }^{158}$ On the other hand, some courts have declined to follow this precedent. ${ }^{159}$ The court in Sherman $v$. Jones addressed the issue of whether revealing an inmate's HIV status in the presence of other inmates violates the Fourth Amendment. ${ }^{160}$ The court refused to provide constitutional protection:

It may well be sensible public policy to provide legal protection to ensure the privacy of medical records. Indeed, most persons would so conclude, although perhaps not in all circumstances or for all kinds of medical information. Yet, even assuming that privacy protection should be accorded to an individual's medical information, the nature and scope of that protection is more sensibly determined by elected legislators via state or federal statute, rather than by judicial stretching of the constitutional text to reach a subject not explicitly treated in the text. ${ }^{161}$

Existing case law shows a rigid dichotomy. ${ }^{162}$ If the Government forced its citizens to undergo microchipping, some courts would probably strike down

153. Ramesh, supra note 16 , at $387-88,390$.

154. See Schmerber v. State of California, 384 U.S. 757 (1966) (The Supreme Court held that the search and seizure was reasonable because the individual was convicted and thus subject to greater restraints on liberty).

155. See United States v. Westinghouse Electric Corp., 638 F.2d 570 (3rd Cir. 1980).

156. See Doe v. City of New York, 15 F.3d 264, 267 (2nd Cir. 1994).

157. See id. at 268.

158. See United States v. Knotts, 460 U.S. 276, 281 (1983).

159. See, e.g., Sherman v. Jones, 258 F. Supp. 2 d 440 (E.D. Va. 2003).

160. See id.

161. Id. at 444-45.

162. See, e.g., id.; see also Doe, 15 F.3d at 264 (The court limited the accessibility of personal information.) 
such a mandate as unconstitutional. People possess reasonable expectations of privacy and assume that information placed on a microchip will not be revealed to others. The microchip is placed within one's body and cryptically protected with passwords, safeguards that would probably not be in place if there were no privacy expectations. ${ }^{163}$ In Doe v. City of New York, the court found a constitutionally-protected interest in Doe's HIV status. ${ }^{164}$ Similarly, protections should extend to a microchip with medical information, perhaps information detailing HIV status like in the Doe case.

\section{Reasonableness}

The second prong of the Supreme Court's Fourth Amendment analysis looks to the reasonableness of forced intrusion by the Government. ${ }^{165}$ In Winston v. Lee, the Supreme Court held that "[ $t]$ he reasonableness of surgical intrusions beneath the skin depends on a case-by-case approach, in which the individual's interests in privacy and security are weighed against society's interests in conducting the procedure. ..."166 Basing its decision on the unreasonable nature of surgical intrusion, the Supreme Court prohibited Virginia from forcing a robbery suspect to undergo surgery in order for doctors to remove a bullet from the suspect's chest. ${ }^{167}$

In Schmerber v. California, the Court looked to "the extent to which the procedure may threaten the individual's safety or health, the extent of intrusion upon the individual's dignitary interest in personal privacy and bodily integrity, and the community's interest. . .."168 Furthermore, the Supreme Court determined that "[s]urgery without the patient's consent, performed under a general anesthetic to search for evidence of a crime, involves a virtually total divestment of the patient's ordinary control over surgical probing beneath his skin." 169

Privacy advocates may encounter several roadblocks when arguing against the reasonableness of mandatory microchipping. Advocates of microchipping could distinguish human-implantable chips from the type of intrusion the Supreme Court prohibited in Lee. ${ }^{170}$ During microchip implantation, a patient does not receive general anesthesia. ${ }^{171}$ The health risks involved are debatable, but VeriChip asserts that few risks accompany the chip. ${ }^{172}$ The microchip is

163. See generally RFID Tags, supra note 7 (detailing the safeguards put in place for human-implantable microchips).

164. See Doe, 15 F.3d at 264.

165. See Kyllo, 533 U.S. at 27-28.

166. Winston v. Lee, 470 U.S. 753,754 (1985).

167. Id.

168. Id. See also Schmerber, 384 U.S. 757.

169. Id.

170. See id.

171. See CNN, Microchips in Humans, supra note 19.

172. See VeriChip Corporation, Letter to Partners, Patients, Customers and Friends, 
like a mere vaccination, which the Government, in effect, requires. ${ }^{173}$

In addition, the Government has the capacity to establish several reasons for microchipping individuals with Alzheimer's disease, not to mention the general population. As stated by the VeriChip Corporation, microchips aid efficient patient identification, an important interest in some medical emergencies. ${ }^{174}$ Nonetheless, this does not take into consideration the nature of the "vaccination." The microchip contains a personal identification number that, if properly entered into a password-protected database, potentially reveals an individual's personal, medical information. ${ }^{175}$ Courts will undoubtedly be skeptical of such a mandate. ${ }^{176}$

\section{B. Fifth Amendment}

In part, the Fifth Amendment provides that a citizen has immunity from self-incrimination. ${ }^{177}$ Traditionally, the Supreme Court only applied the Fifth Amendment to verbal self-incrimination and physical trespass in the area of wiretapping. ${ }^{178}$ Consequently, electronic eavesdropping by Government agents did not fall under the protections afforded by the Fifth Amendment. ${ }^{179}$

The Supreme Court has since broadened its view of the Fifth Amendment. ${ }^{180}$ Beginning in Silverman $v$. United States, the Court held that the Government's insertion of a "spike mike" into a wall of a row house in order to eavesdrop on a conversation violated the Fifth Amendment. ${ }^{181}$ The Court based its decision not on trespass, but " upon the reality of an actual intrusion into a constitutionally protected area." "182 Moreover, in Katz, the Court completely dispensed with the idea that only trespass triggers the Fifth Amendment. 183

Today, the Court has expanded Fifth Amendment protection to include removal of objects from an individual's body. ${ }^{184}$ In Rochin v. California, deputy sheriffs and a hospital physician forced defendant Rochin to vomit, which allowed the sheriffs to find two capsules containing morphine. ${ }^{185}$ Rochin was subsequently arrested. ${ }^{186}$ The Supreme Court reversed his conviction, finding

http://www.verichipcorp.com/files/letter_scott.pdf (last visited Feb. 20, 2009).

173. See generally CNN, Microchips in Humans, supra note 19 (detailing the microchip's implantation process, which is described as feeling like a shot).

174. See Eschet, supra note 24, at 309.

175. See RFID Tags, supra note 7.

176. See Ramesh, supra note 16 , at 387-88.

177. See Id.

178. See Kobelev, supra note 117 , at 332.

179. See id.

180. See id.

181. See id.

182. Id. at 336 (quoting Silverman v. United States, 365 U.S. 505 (1961)).

183. See id.

184. See Ramesh, supra note 16 , at 397.

185. See Rochin v. California, 342 U.S. 165, 166 (1952).

186. See id. 
that it was unconstitutional under the Fifth Amendment, as well as under the Fourteenth. ${ }^{187}$ In his concurring opinion, Justice Black explained that "a person is compelled to be a witness against himself not only when he is compelled to testify, but also when . . . incriminating evidence is forcibly taken from him by a contrivance of modern science."

As it stands today, the "privilege against self-incrimination focuses on three basic elements: compulsion, incrimination, and testimonial communication." 189 Assuming that the Government compels the gleaning of information from a microchip and the information proves to be incriminating in some way, the crucial question becomes whether the production of the microchip's information would qualify as "testimonial" under the Fifth Amendment.

The Supreme Court has addressed the definition of "testimonial" in several circumstances. ${ }^{190}$ For example, in Schmerber, the Court sustained the admissibility of evidence obtained from a compulsory blood test. ${ }^{191}$ The Court differentiated between the donor/suspect's act, testimony, and evidence to support its decision. ${ }^{192}$ In essence, the testimony came from the chemical analysis of the blood, not from the defendant's involvement with the extraction of the blood. ${ }^{193}$ The Supreme Court, however, also wrote "[ $\left.t\right]$ hat we today hold that the Constitution does not forbid the State's minor intrusions into an individual's body under stringently limited conditions in no way indicates that it permits more substantial intrusions, or intrusions under other conditions." 194 In so stating, however, the Court notably did not furnish a set of guidelines by which to measure "more substantial intrusions."

In an analogous case, Doe, the target of a grand jury investigation failed to disclose some records of foreign bank accounts. ${ }^{196}$ The suspect refused to sign a consent order allowing the banks to release any such records to the prosecutor, despite Government attempts at compulsion, claiming the right against selfincrimination. ${ }^{197}$ Once again, the Court held that the Fifth Amendment privilege was not implicated by forcing the target to sign a release of the records because the accused was not being forced "to disclose the contents of his own mind."198

The Fifth Amendment's privilege against self-incrimination would therefore not likely cover microchip implants in humans. In light of Schmerber and

187. See id. at 174.

188. Id. at 175 (Black, J., concurring).

189. Fisher v. United States, 425 U.S. 391, 408 (1976).

190. See, e.g., Schmerber, 384 U.S. at 761 .

191. Id. at 765 .

192. Id.

193. Id.

194. Id. at 772 (emphasis added).

195. Id.

196. Doe, 487 U.S. at 202-03.

197. Id. at 203.

198. Id. at 211 (quoting Curcio v. United States, 354 U.S. 118, 128 (1957)). 
Doe, the act of implantation itself would not be incriminating. ${ }^{199}$ A microchip could be viewed in a light similar to that of blood test evidence or bank records. Although the microchip is placed within one's body, the information comes from scanning the microchip, not from the patient's actual communication of information. ${ }^{200}$ The information is stored on a capsule and does not involve "the contents of [one's] own mind.",201 Thus, following this discomforting chain of thought, the Fifth Amendment would not prohibit the Government from introducing medical information forcibly recovered from an individual's microchip at trial, no matter how personal or incriminating it may be.

\section{Due Process Clause}

While at the New York Court of Appeals, Justice Cardozo described the right to privacy and more specifically the right to bodily integrity: "[e]very human being of adult years and sound mind [has] a right to determine what shall be done with his own body."202 The Due Process Clause of the Fourteenth Amendment guarantees the personal liberty of Americans and protects certain unenumerated fundamental rights and interests. ${ }^{203}$ The Supreme Court has articulated that one such fundamental right is a right to privacy, which stems from the penumbras from various provisions of the Bill of Rights. ${ }^{204}$ Because privacy is a fundamental liberty interest under the Fourteenth Amendment, courts apply the strict scrutiny test. ${ }^{205}$ In other words, courts examine whether a state pursuing a compelling governmental interest requiring the infringement of the right to privacy does so in the least restrictive manner possible. ${ }^{206}$

In the past, the Supreme Court has recognized a number of compelling governmental interests in the area of medical treatment, for which states have narrowly tailored approaches to achieve their objectives. For example, in the famous abortion case, Roe $v$. Wade, although the Court struck down the criminal abortion laws at issue, it still established a trimester framework allowing for abortions in only certain circumstances, thus recognizing the State's compelling interests in the health of the mother and in the potentiality for human life. ${ }^{207}$ In a subsequent decision, the Court broadened the scope of a state's compelling interests in the area of abortion. ${ }^{208}$ It held that a state has a compelling interest

199. See Ramesh, supra note 16 , at 397.

200. See RFID Tags, supra note 7, for an explanation of how information may be retrieved from a microchip.

201. Doe, 487 U.S. at 211; see RFID Tags, supra note 7, for a description of the storage capabilities of the human-implantable microchip.

202. Schloendorff v. Soc'y of N.Y. Hosp., 211 N.Y. 125, 129 (1914), overruled on other grounds by Bing v. Thunig, 143 N.E.2d 3 (N.Y. 1957).

203. Griswold, 381 U.S. at 482.

204. Id. at 484.

205. See id. at 485.

206. See id.

207. Roe v. Wade, 410 U.S. 113, 162 (1973).

208. See Planned Parenthood of Se. Pa. v. Casey, 505 U.S. 833 (1994). 
in informing the woman's choice, as well as in the interests already recognized in Roe-fostering the health of the woman and persuading the woman to care for the well-being of the fetus. ${ }^{209}$

Proponents of microchipping could use similar arguments to justify further intrusion by the Government into the privacy realm, perhaps advocating the forced microchipping of Alzheimer's patients. The Government could potentially avoid the prohibitions of the Fourteenth Amendment by asserting justifications taken explicitly from both Roe and Planned Parenthood of Se. Pa. $v$. Casey, such as the compelling interest in the health of the compromised Alzheimer's patient. ${ }^{210}$ Specifically, many individuals who receive implants do so to create ease and efficiency in identification and access to medical records. ${ }^{211}$

In another arena of medical privacy cases, the Supreme Court has examined the putative right to die. In Cruzan v. Director, Missouri Department of Health, the Court held that while a patient may elect to terminate treatmentincluding life support-and that failure to abide by that choice would be inhumane, the State had a substantial interest in the patient's health and could rightfully restrict that decision to the patient alone by demanding a clear indication of the patient's wishes. ${ }^{212}$ In making its determination, the Court looked to history and tradition in the common law. ${ }^{213}$ In a related case, Washington $v$. Glucksberg, the Court specifically recognized the State's interests in preventing assisted suicide. $^{214}$ It held that the State possessed an interest in protecting depressed patients, as well as in preventing a slippery slope of prejudicial or premature decisions and furthering negative stereotypes about the terminally ill or permanently disabled. ${ }^{215}$ Commentators have questioned the far-reaching impact of the Court's decision in protecting the elderly population. ${ }^{216}$ Specifically,

[s]uicide especially afflicts the . . elderly. Of persons over sixty-five, one in seven suffers from depression but the great majority receives no treatment. Elderly persons are apt to hide their symptoms out of shame or fear of seeming weak. Doctors often fail to recognize the signs of depression in their older patients. . . ${ }^{217}$

The Court's analyses from these cases may be applied to potential situa-

209. Id. at 846 .

210. See Roe, 410 U.S. at 113; see also Casey, 505 U.S. at 833.

211. See Eschet, supra note 24, at 309.

212. Cruzan v. Dir., Mo. Dep't of Health, 497 U.S. 261 (1990).

213. See id. at 269-79.

214. Washington v. Glucksberg, 521 U.S. 702, 728-29 (1997).

215. See id. at 730-32.

216. See generally Ruth C. Stern \& Herbie DiFonzo, Terminal Ambiguity: Law, Ethics and Policy in the Assisted Dying Debate, 17 B.U. PuB. INT. L.J. 99 (2007).

217. Id. at 103 . 
tions created by abuses in microchipping Alzheimer's patients. In actuality, the cases may support a Government prohibition against microchipping. As with assisted suicide, elderly Alzheimer's patients tend to hide their symptoms, making it difficult for doctors to accurately render a diagnosis. ${ }^{218}$ Furthermore, courts would likely follow Supreme Court precedent and examine tradition. ${ }^{219}$ Because microchipping has not been established in the nation's tradition and courts are usually wary of bodily intrusion, the Fourteenth Amendment might actually justify the Government in protecting its citizens from the use of human-implantable microchips.

Tradition, however, is subject to interpretation. ${ }^{220}$ In Cruzan, for example, the Court held that the fundamental right at issue involved the right to die. $^{221}$ In Glucksberg, the respondents tried to define assisted suicide as properly fitting within the right to die, arguing for protection of the "personal choice by a mentally competent, terminally ill adult. . .."222 The Court, however, refused to adopt this interpretation and classified the interest at issue as "assisting another in the commission of self-murder."223

With regard to microchipping, a court could investigate tradition on a broad scale. Instead of looking at the existence of microchipping in the nation's history, a court could analyze tradition in light of the right to make medical choices or the right to control one's body. Depending on a court's interpretation, it could potentially find tradition in the law that supports microchipping.

\section{OTHER CONSIDERATIONS}

In addition to the privacy issues that may arise because of humanimplantable microchips, other considerations also exist as well. These include concerns about consent and power of attorney.

\section{A. Consent}

Consent may be one of the biggest potential problems involved in microchipping. Informed consent is premised on the principle that every adult individual of a sound mind has the right to bodily integrity and the right to control

218. See id.; see also infra pp. 38-42 (discussing consent and difficulties that doctors confront in diagnosing Alzheimer's Disease).

219. See Cruzan, 497 U.S. at 269-79.

220. See Richard E. Shugrue, "A Fate Worse Than Death": An Essay on Whether Long Times on Death Row are Cruel Times, 29 CREIGHTON L. REV. 1, 22 (1995) ("The Court quite often has invoked tradition as a source of fundamental rights. But what is tradition? Is tradition what lawmakers say? Or is tradition the custom of a community?").

221. See Cruzan, 497 U.S. at 277.

222. Glucksberg, 521 U.S. at 708.

223. Id. at 705 . 
his or her medical treatment. ${ }^{224}$ In very limited circumstances, however, an exception to this right exists. ${ }^{225}$ Specifically, this right may be curtailed when the patient presents a danger to himself or to others. ${ }^{226}$ When adhering to the established consent doctrine, a physician, who is going to implant a patient with a microchip, first needs to obtain the patient's consent or permission from a person legally authorized to give consent in the patient's stead. ${ }^{227}$

VeriChip's new campaign to implant Alzheimer's patients, however, actually magnifies potential consent problems. For example, "[p]atients with Alzheimer's disease and other dementias have high rates of incompetence with regard to [competency] decisions. ... "228 In fact, according to a recent study, "more than half of patients with mild-to-moderate dementia may have impairment, and incompetence is universal among patients with severe dementia."229

It may seem like an obvious solution just to identify which patients requesting implantation may be deemed incompetent and then rely on power of attorney to determine the best interests of that individual. Identification of incompetency, however, is not a simple task. ${ }^{230}$ "[D]ifferentiating capable from incapable subjects remains an issue despite the aid of standardized tools. More research is needed to understand the relationship between subject factors (performance on ability measures) and categorical judgments about their capacity.",231

Not only does identification of competency cause doctors and researchers alike to throw in the towel, but actual identification of Alzheimer's disease in a patient proves complex as well. For example, doctors diagnose many individuals with Alzheimer's disease after it has progressed beyond its early stage and has already rendered the patient incompetent. ${ }^{232}$ This may stem from the fact that " $[\mathrm{t}]$ here's no clear-cut line between normal changes and warning signs.",233 In essence, in attempting to diagnose Alzheimer's disease, doctors must differentiate between a mere change in functionality due to normal aging and a change due to actual problems with brain activity. This is a difficult task consi-

224. See Kulak v. City of New York, 88 F.3d 63, 74 (2nd Cir. 1996).

225. See id.

226. See id.

227. See Dunlap v. Marine, 242 Cal. App. 2d 162, 168-69 (2nd Dist. 1966); see also Chambers v. Nottebaum, 96 So.2d 716, 718-19 (Fla. Dist. Ct. App. 1957).

228. Paul S. Appelbaum, M.D., Assessment of Patients' Competence to Consent to Treatment, 357 NEW ENG. J. MED. 1834, 1835 (2007).

229. Id.

230. See generally Alzheimer's Association, What is Alzheimer's?, http://www.alz.org/ alzheimers_disease_what_is_alzheimers.asp (outlining the fuzzy differences between Alzheimer's and normal age-related memory changes) (last visited Feb. 20, 2009).

231. Scott Y. H. Kim, et al., Assessing the Competence of Persons with Alzheimer's Disease in Providing Informed Consent for Participation in Research, 158 AM. J. PSYCHIATRY 712, $712(2001)$.

232. See Alzheimer's Association, Warning Signs of Alzheimer's, http://www.alz.org/ alzheimers_disease_symptoms_of_alzheimers.asp (last visited Feb. 20, 2009).

233. Id. 
dering the doctor's limited access to the inner workings of the brain. ${ }^{234}$ For instance, early-stage Alzheimer's disease affects memory, thinking, and concentration, characteristics that accompany normal aging as well, although to a lesser extent. ${ }^{235}$

Also, diagnosis of Alzheimer's disease proves tricky for doctors because "Alzheimer's patients are quite successful at hiding [their] symptoms . . .236 In fact, Alzheimer's patients typically deny the severity of their problems, even to themselves. ${ }^{237}$ This makes it difficult for others to perceive the presence of dementia until it has progressed into a much more serious stage. ${ }^{238}$ As a result of these problems in identifying Alzheimer's disease, a doctor, a patient, or the patient's family may not know to take the next step and question the individual's competency.

Additionally, the law presumes "competency rather than incompetency." 239 Although this presumption serves beneficial purposes in some cases, in the case of microchipping Alzheimer's patients, it only hurts chances for a logical and competent decision. Because of Alzheimer's patients' ability to hide their symptoms from others, a court would have no reason to question competency. Even if their competency was questioned, the burden of proof would be on the individual attempting to prove the patient's incompetence for the court to deprive a patient of their right to choose or avoid medical treatment or a procedure like microchipping. ${ }^{2}$

Subsequently, the VeriChip Corporation's push toward implantation of Alzheimer's patients treads on unstable ground. Assuming an individual has actually been correctly diagnosed with Alzheimer's disease, no set of brightline rules exists that will aid in a competency determination. If microchipping should be easily accessible to incompetent individuals, then perhaps patients with extreme forms of debilitating insanity should also be allowed to make decisions about important medical procedures.

\section{B. Power of Attorney}

Power of attorney also raises a number of other potential problems regarding human-implantable microchips. State and federal laws allow for individuals to formally authorize someone, perhaps a friend or a family member, to make medical decisions for them when they are incapacitated, imbuing them

234. Id.

235. Id.

236. Harvard Health Publications, Anticipating the Future, http://mercksource.com/ ppdocs/us/cns/harvard-health-reports/MerckSHR-Alzheimers082906/sections/sect12.htm (last visited February 18, 2008).

237. Id.

238. See id.

239. R. H. Lockwood, Mental Competency of Patient to Consent to Surgical Operation or Medical Treatment, 25 A.L.R.3d 1439 (1969).

240. See id. 
with power of attorney. ${ }^{241}$ Theoretically, this individual should be an advocate for the patient, attempting to ensure compliance with the patient's desires. ${ }^{242}$ In other words, it should be "someone who will articulate their wishes to providers and who will also provide patients with the needed assistance and support required to maneuver through the confusing labyrinth of health care delivery.,"243

Some patients, whether suffering from Alzheimers or another illness, do not, however, appoint a proxy. ${ }^{244}$ But will the proxy have the patient's best interests at heart? In light of human-implantable microchips, a proxy may have personal motivations to have a patient chipped-for example, increased ease in caretaking and quick identification. ${ }^{245}$ These efficiency concerns may overshadow a patient's wishes. This also opens up the door for more litigation when concerned family members, friends, and other individuals want a say in the proxy's decisions. ${ }^{246}$

Even if an Alzheimer's patient does appoint a proxy through advance directive, ${ }^{247}$ the advance directive system possesses a number of flaws. ${ }^{248}$ For example, an advance directive may actually be overridden in some states in very limited cases. ${ }^{249}$ Thus, even if an Alzheimer's patient does not want to be chipped and directs such a prohibition in advance, there remains a slim chance that the patient's proxy could get this mandate overridden at a later date.

\section{SOLUTION: FORCING THE STATES INTO THE LIMELIGHT}

Several approaches may be taken to prevent the problems inherent in human-implantable microchips. The legislature could act (or not act) in several extreme and opposite ways: it could pass a ban on microchipping humans or it could completely disregard the potential conflicts. The best approach, however,

241. Susan Werthem, Front-End First in Line to Ensure Patients Gain Needed Support: Patient Advocates Help Meet Patient Needs, 16 No. 2 HealthCARE Registration 3, 3 (2006).

242. Id.

243. Id.

244. Id.

245. See Eschet, supra note 24, at 309.

246. Charles M. Key, Who Will Decide?, 42 TENN. B.J. 12, 19(2006).

247. An advance directive details how an individual wants certain medical decisions made if they are unable to make them or gives authorization for someone else to make such decisions on their behalf.

248. See id.

249. From 2000 to 2005 , the Terri Schiavo controversy raged on. Schiavo's husband wanted to remove her feeding tube, but Schiavo's parents adamantly opposed removal. Thomas Mayo stated in the Journal of Health Law that:

No living will and no other piece of paper known to mankind, will avert the cataclysmic clash of family members who are determined to control the decisionmaking for an incompetent patient ... [I]s it likely that the Schiavo controversy would have been averted if Terri Schiavo had simply designated her husband as her proxy decisionmaker in a durable (or medical) power Id. of attorney? Probably not. 
would be to advocate restrictive legislation by the states. ${ }^{250}$ State governments would be the most efficient mechanism by which to pass legislation, partially because of their past involvement in actively regulating RFID. ${ }^{251}$

Without completely squelching this new area of science, safeguards are especially important because the VeriChip Corporation's new publicity campaign targets individuals with Alzheimer's disease, as well as their families and caregivers. Statutory protection against misuse of the human-implantable microchip should cover the general population. Patients with Alzheimer's disease, however, are often completely defenseless against exploitation. ${ }^{252}$ In essence, advocates for the elderly and those with mental disabilities have asserted as follows:

The shameful history of benign and sometimes malignant neglect of persons with mental disabilities is well understood: the deep stigma and unredressed discrimination, the deplorable living conditions, and the physical and social barriers preventing their integration and full participation in society. Countless promises have been made to right the wrongs, but new forms of neglect have always emerged. The mentally disabled have ended up in prison, in equally deplorable adult homes, or on the streets, homeless and destitute, while the wider society has averted its eyes. ${ }^{253}$

As a result, extra care should be given in ensuring their protection.

\section{CONCLUSION}

In summary, implanting individuals with microchips implicates a number of legal and social concerns. For instance, the procedure and technology behind microchipping has not been tested at length and raises a number of policy issues. Also, despite the lack of legislation or case law on human-implantable microchips, similar areas of the law hint at potential problems. Specifically, the protections implicit within the text of the Constitution may not apply to microchipping, leaving society and individuals with Alzheimer's disease open for governmental manipulation. Also, consent and power of attorney may add to the complexities of the issue.

250. See infra pp. 15-16.

251. See generally Kobelev, supra note 117, at 339-41 (supporting the idea of more regulation for RFID).

252. See Lawrence O. Gostin, International Human Rights Law and Mental Disability, HASTINGS CENTER REP., (March-Apr. 2004), http://www.who.int/ethics/en/Gostin.pdf (last visited Feb. 20, 2009).

253. Id. 
Therefore, in order to protect individuals with Alzheimer's disease, state governments should carefully monitor this up-and-coming technology. If a blind eye is turned to the potentiality for chip abuse, especially regarding the elderly population, we could really be "on the verge of creating a surveillance society in America, where every movement, every action - some would even claim, our very thoughts - will be tracked, monitored, recorded and correlated." 254

254. CNN, Microchips in Humans, supra note 19 (quoting Barry Steinhardt, director of the Technology and Liberty Program at the American Civil Liberties Union in Washington D.C). 